\title{
HISTOLOGICAL STAINING PROPERTIES OF KHAYA SENEGALENSIS WOOD DUST EXTRACTS: A PRELIMINARY STUDY
}

\author{
Azubuike Nkiruka $\mathrm{C}^{* 1}$, Ikele Ikenna $\mathrm{T}^{2}$, Onyemelukwe Anulika $\mathrm{O}^{1}$, Maduakor Uzoamaka $\mathrm{C}^{1}$, Onwukwe \\ Okechukwu S1, Maduakor-Oparah Chioma Lㄹ, Chukwu Ikechukwu J1, Okoye Rita $\mathbf{O}^{4}$ \\ ${ }^{1}$ Department of Medical Laboratory Sciences, Faculty of Health Sciences \& Technology, College of \\ Medicine, University of Nigeria, Nigeria \\ ${ }^{2}$ Department of Anatomy, Faculty of Basic Medical Sciences, College of Medicine, University of Nigeria, \\ Nigeria \\ ${ }^{3}$ College of Medicine, University of Lagos Teaching Hospital, Lagos State, Nigeria \\ ${ }^{4}$ Allied Specialist Hospital and Diagnostic Centre, Gwagwalada, Abuja, Nigeria \\ *Correspondence to Azubuike N.C.: Department of Medical Laboratory Sciences, Faculty of Health \\ Sciences and Technology, College of Medicine, University of Nigeria, Enugu Campus. Tel: \\ +2348036711136. E-mail: nkiruka.azubike@unn.edu.ng
}

\begin{abstract}
Crude aqueous and methanol extracts of Khaya senegalensis wood dust were employed as histological stains for the demonstration of general tissue architecture. Preliminary phytochemical screening of the extracts was conducted. Mixtures of the extracts of $K$. senegalensis in acidic, alkaline and neutral solutions were used to stain tissue sections. Preliminary phytochemical screening revealed that $K$. senegalensis extracts contains flavonoids, saponins, tannins, glycosides and reducing sugars. Optimum staining time was 15 minutes for both extracts and they stained the tissues in different shades of red and brown in the various media used. The best and worst stain uptake of tissues was observed with both extracts in alkaline and neutral media respectively. Mordant preparation of the extracts produced no significant staining difference from the non-mordant preparations. Staining solutions of the extracts have better affinity for the cellular cytoplasm and hence gave a good contrast when compared with Hematoxylin and Eosin control sections. In conclusion, Khaya senegalensis wood extract is a promising histological stain for the demonstration of general tissue architecture.
\end{abstract}

Key words: Khaya senegalensis, wood dust, stain, histology, mordant

\section{INTRODUCTION}

Khaya senegalensis commonly known as African mahogany is a tree belonging to the family Meliaceae. It is a deciduous evergreen tree with height of about 15 to $30 \mathrm{~m}$ and is native to Cote D'Ivoire, Cameroon, Chad, Nigeria, Ghana, Senegal and other West African countries, though exotically found in Cuba, Australia and
India (Von Maydell, 1986). The bark possesses reddish tinged scales and its leaves are compound with $3-7$ pairs of usually opposite leaflets of about $7-12 \mathrm{~cm}$ long. It possesses flowers and is a fruit producing tree (Bokkestijn and Francis, 1986). 
According to Hill (1952), it is renowned for its beautiful closely gained hard red-brown wood and the hard timber is utilized for furniture making, high class joining, sculpture, boat building flooring and veneer. Mahogany bark extracts have been used as wood floor stain and occasionally for tanning leather producing a rich mahogany red colour (Lamb, 1966).

Furthermore, extracts of the parts of $K$. senegalensis have a considerable medicinal reputation as a vermifuge, taenicide, laxative, anti-inflammatory, antidiarrheal, antitrypanosomal agent, wound healing agent and disinfectant, depurative and for treating gonorrhoea, malaria and rheumatism (OliverBever, 1960; Atawodi, 2005; Zhang et al. 2007; Nwosu et al., 2012; Abdel-Wareth et al., 2014, Orendu et al., 2016). Its roots are also noted for treatment of mental illness, syphilis, leprosy, against sterility and as an aphrodisiac (Vogt, 1995).

In histochemistry, histology and histopathology, the use of dyes aids in the microscopical examination of tissues and cells. Several natural dyes obtained from natural sources such as plants, insects and the soil have been used while the synthetic dyes are obtained through chemical reaction (Carleton, 1976). Hematoxylin, obtained from the log wood Haematoxylon campechianum is the most routinely used histological dye for nearly all tissue specimens (Bancroft and Layton, 2013). Other natural dyes from plants that have been shown to stain tissues include extracts of Hibiscus sabdarifa leaves, Pterocarpus osun leaves, Morinda lucida roots, Rhizomes of Curcuma longa, Lawsonia inermis leaves and Certonia siliqua bark (Avwioro et al., 2005a, 2005b and 2007; Azubike et al, 2011; Okpidu et al, 2012).

Although synthetic dyes are efficient they are not eco-friendly and are becoming expensive; hence they are no longer affordable to many small laboratories and developing countries (Eom et al., 2001). In addition, the limited application and recent withdrawal of some of them is due to the hazard they pose to human and animal health (Bhuyan and Saika, 2004; Alturkistani et al., 2016). With the global acceptance of the use of environmentally friendly and biodegradable material, there has been an increase on research into the discovery of more natural dyes (Eom et al., 2001). K. senegalensis extract is used for dyeing fabrics (Nikiema and Pasternak, 2008) but to the best of our knowledge, there is draught of information on its use as a histological dye for tissue sections. In lieu of this, a natural dye extracted from $K$. senegalensis wood dust is being investigated as a possible histological stain in the present study.

\section{MATERIALS AND METHOD}

Preparation of the Crude extracts of Khaya senegalenisis wood dust

Aqueous wood extract: Wood flakes from a 4feet timber of Khaya senegalensis was obtained from a timber dealer at Kenyatta Timber Shade in Enugu metropolis, Enugu State, Nigeria. The flakes were pulverized in a saw dust grinding machine to obtain a fine powder. $500 \mathrm{~g}$ of $\mathrm{K}$. senegalensis powder was soaked in $800 \mathrm{mls}$ of distilled water and the mixture was boiled for 10 mins and left to cool at room temperature. The mixture was filtered with a muslin cloth and subsequently with Whatman No. 1 filter paper. Methanol extract: About $800 \mathrm{~g}$ of $\mathrm{K}$. senegalensis wood fine powder was subjected to methanol extraction by maceration under gentle agitation for 48 hours at room temperature using 2.5 litres of $75 \%$ methanol. A reddish brown coloured filtrate was obtained after sieving with a Muslin cloth and subsequently with Whatmann No. 1 filter paper. The filtrate was concentrated by evaporation of the methanol at room temperature. 
Phytochemical analysis

The phytochemical constituents of the aqueous and methanol extracts of Khaya senegalensis were identified by qualitative chemical tests [Trease and Evans, 2002]

\section{Histological processing of the tissue samples for staining}

Two English Angora rabbits were euthanized using diethyl ether and the liver, heart, intestine, lungs, kidney, and skin samples of both animals were excised. $3 \mathrm{~mm}$ thick tissues were obtained from each organ. The tissue samples were fixed in $10 \%$ formol saline for 4 days to ensure adequate permeation of the organs in the fixative. The tissues were further processed using the paraffin wax embedding technique for light microscopy with an automatic tissue processor by dehydrating through increasing grades of alcohol, two changes of xylene for clearing of the tissues, and wax infiltration through two changes of paraffin wax at $70^{\circ} \mathrm{C}$. The tissues were further embedded in plastic tissue cassettes to give them external support prior to sectioning using molten paraffin wax. Ten (10) sections of $5 \mu \mathrm{m}$ were obtained from each tissue using a rotary microtome [Hertz 150 rotary microtome, Cambridge model]. The sections were floated on water bath, picked with slides (Pyrex quality) and adhered unto the slides by drying at $65^{\circ} \mathrm{C}$ for $30 \mathrm{mins}$

Preparation of $K$. senegalensis staining solutions For the staining solutions of the aqueous extract of $K$. senegalensis [AEKS], 100mls each of the following staining solutions were prepared: (i) $A E K S$ boiled with $10 \mathrm{~g}$ of potash alum for 10 mins; (ii) $A E K S$ boiled with $10 \mathrm{~g}$ of caustic potash [potassium hydroxide - $\mathrm{KOH}$ ] for 10 mins; and (iii) $A E K S$ boiled in $10 \mathrm{~g}$ of $\mathrm{KOH}$ for 5 mins, cooled and treated with $0.175 \mathrm{~g}$ of potassium permanganate [per $10 \mathrm{mls}$ of the solution]

The staining solutions of the methanol extract $K$. senegalensis [MEKS] were prepared in different solutions as described by Avwioro et al., (2007). $5 \mathrm{~g}$ of the MEKS was dissolved in $100 \mathrm{ml}$ of each of the following solutions: (iv) distilled water; (v) 70\% ethanol; (vi) 70\% ethanol saturated with a mordant, 'potash alum' [aluminium potassium sulfate]; (vii) $1 \%$ ammonium hydroxide in $70 \%$ ethanol; and (viii) $1 \%$ acetic acid in $70 \%$ alcohol.

\section{Staining method}

180 sections were de-waxed with xylene and taking through descending grades of alcohol and finally into water prior to staining. The staining solutions employed to stain the sections were: $A E K S$ alone, solutions (i) to (iii) of $A E K S$ and solutions (vi) to (viii) of MEKS. Exploratory trials were conducted to determine the optimum staining time for the staining reactions of the MEKS and AEKS staining solutions. The staining solutions were also used individually as counter stains in replacement of Eosin in the Hematoxylin and Eosin [H and E] staining technique (Baker et al, 2001). Control sections for the demonstration of general tissue structure were obtained by the $\mathrm{H}$ and $\mathrm{E}$ staining technique.

\section{RESULTS}

Phytochemical screening of Khaya senegalensis wood dust

The wood dust extracts of $K S$ contained flavonoids, saponins, tannins and glycosides and reducing sugars [Table 1]. Staining reactions of the Crude MEKS and AEKS

The optimum staining for both extracts was about 15 mins. Figure 1 (I-VII) are photomicrographs of tissue sections stained with $K$. senegalensis extracts. Both extracts stained the acid and basic components of the tissues though a stronger affinity for the basic components of the tissue (cytoplasmic structure) was observed. Very poor tissue colour uptake was obtained after staining with preparation of MEKS in distilled water (data not 
shown) but a satisfactory stain uptake when 1-III).

dissolved in $70 \%$ ethanol was observed (Figure

Table 1: Phytochemical screening of MEKS and AEKS

\begin{tabular}{|l|c|c|}
\hline \multicolumn{1}{|c|}{ CONSTITUENTS } & AEKS. & MEKS \\
\hline Flavonoids & +++ & ++ \\
\hline Alkaloids & - & - \\
\hline Saponins & +++ & +++ \\
\hline Tannins & ++ & +++ \\
\hline Glycosides & ++ & +++ \\
\hline Steroids & - & - \\
\hline Reducing sugars & +++ & +++ \\
\hline
\end{tabular}

Key: -: Absent; +: Trace; ++: Moderate; +++: Abundant; AEKS: Aqueous Extract; MEKS: Methanol Extract

Table 2: $\quad$ Various staining solutions of Khaya senegalensis extracts and colour uptake by tissues

\begin{tabular}{|c|l|c|}
\hline Type of extract & Staining solutions used & Tissue colour uptake \\
\hline Methanol extract & $\begin{array}{l}1 \% \text { Acetic acid in 70\% alcohol as a } \\
\text { counter stain for Hematoxylin }\end{array}$ & Pinkish brown \\
\cline { 2 - 3 } & $\begin{array}{l}1 \% \text { ammonium hydroxide in } 70 \% \text { alcohol } \\
\text { as a counter stain for Hematoxylin }\end{array}$ & Deep brown \\
\cline { 2 - 3 } & $\begin{array}{l}70 \% \text { alcohol as counter stain for } \\
\text { Hematoxylin }\end{array}$ & Pinkish-red \\
\hline Aqueous extract & $\begin{array}{l}\text { Boiled with potash alum and used as a } \\
\text { counter stain }\end{array}$ & Light brown \\
\cline { 2 - 3 } & Boiled with caustic potash only & \multicolumn{1}{|c|}{ Red } \\
\cline { 2 - 3 } & Treatment with potassium per manganate & Yellowish brown \\
\hline
\end{tabular}

MEKS in acidic medium produced a satisfactory staining (Figure 1-VI) after staining tissue with hematoxylin. In alkaline medium $[1 \%$ ammonium hydroxide in $70 \%$ ethanol] the MEKS produced an enhanced stain uptake though with fairly moderate definition and differentiation of cellular structures (Figure 1IV). Mordanting did not produce any obvious difference in staining ability of the extracts.

Staining solution of $A E K S$ mixed with potash alum did not produce satisfactory staining effect as a faint colour uptake was observed.
However, AEKS prepared with caustic potash [alkaline media] produced a good, enhanced and well-defined staining effect when used alone ((Figures 1-I) whereas, when used as a counter stain for hematoxylin, it produced a weaker staining effect (Figures $1-\mathrm{V}$ and $1-\mathrm{VII}$ ). Addition of potassium permanganate to $A E K S$ produced an intense yellowish-brown colouration within 60 seconds (Figure 1-II). A summary of the colour uptake of the various staining solutions of the extracts used is shown in Table 2. 

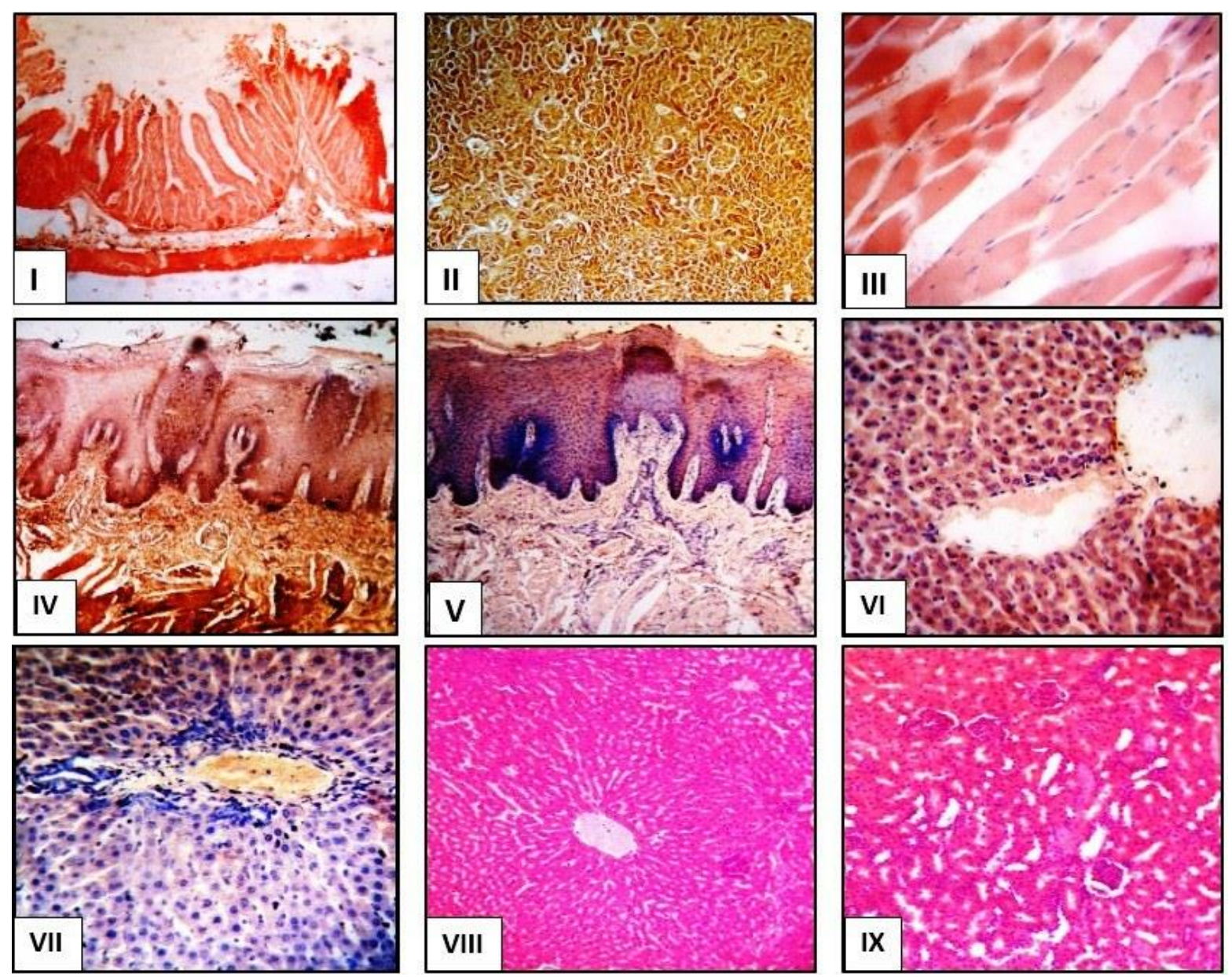

Figure 1 [I-IX]: Photomicrographs of tissue sections stained with the extracts of Khaya senegalensis. I: Jejunum section stained with $A E K S$ boiled with caustic potash [KOH]; II: Kidney section stained with $A E K S$ boiled with $\mathrm{KOH}$ and treatment with potassium per manganate used in replacement of Eosin in the H\&E technique; III : Smooth muscle section stained with MEKS in $70 \%$ ethanol; IV: Skin section stained with MEKS in 1\% ammonium hydroxide in 70\% ethanol; V: Skin section stained with AEKS boiled with $\mathrm{KOH}$ used in replacement of Eosin in the H\&E technique; VI: Liver section stained with MEKS in $1 \%$ acetic acid in $70 \%$ ethanol used in replacement of Eosin in H\&E technique; VII: Liver section stained with AEKS boiled with $\mathrm{KOH}$ used in replacement of Eosin in the H\&E staining technique; VIII \& IX: Control H\&E sections of Liver and Kidney tissues respectively.

\section{DISCUSSION}

The present study has shown the staining ability of the wood extracts of $K S$. The major phytochemical constituents in both extracts of $K S$ were found to be flavonoids, saponins and tannins, however, it is not clear as to which of these compounds contains the active staining principle.

The extracts from $K S$ wood dust was observed to have stained the basic and acidic components of the tissues, but a stronger affinity for the basic structures was noted. Dyes with an affinity for the basic structures of a histological specimen are termed acidic dyes (Ochei and Kolhaktar, 2000; Baker et al, 2001). Two phytochemicals, flavonoids and tannins, found in rich quantities in $K S$ wood extracts, are the most natural phenolic compounds. The dyeing property of a plant extract correlates the appreciable amounts of these phytochemicals in 
the plant (Jondiko and Pattenden, 1989; Shadid et al., 2009). Polyphenolic compounds and phenols are acidic in character because they lose a positive hydrogen ion $\left(\mathrm{H}^{+}\right)$from their hydroxyl group (Kumar et al., 2014). Hence, in dye-tissue reactions, an electrostatic attraction of unlike ions exists whereby the anions of an acidic dye interacts with tissue structures that are rich in cations (Prento, 2009). Plausibly, it may be inferred that the stain from $K S$ wood extract is acidic in nature due to its strong affinity for the basic components of the tissue.

Dyes are able to stain specific tissue structures due to some factors such as $\mathrm{pH}$, ionic strength and mordanting (Hoffman and Bauknecht, 1999). In this study, simple aqueous and alcohol solution of both extracts especially MEKS produced very faint and unsatisfactory staining results. Better staining effects were achieved by altering the $\mathrm{pH}$ (both acidic and alkaline regions) than when used in neutral media. At low $\mathrm{pH}$, a satisfactory staining result was obtained, however at high $\mathrm{pH}$ fostered by ammonium hydroxide and caustic potash $[\mathrm{KOH}]$, intense staining reactions were achieved, although less definition and differentiation of the cellular structures were observed with the use of ammonium hydroxide. These findings connote that the staining component(s) present in $K S$ may be favoured by either a low $\mathrm{pH}$ or a high $\mathrm{pH}$ leading to improved staining quality. Avwioro et al. (2005a), however, reported that some natural and synthetic dyes do not require the addition of a base or an acid.

A mordant is a metallic salt that acts as a bridge between the tissue and stain, hence enabling stain uptake (Ochei and Kolhaktar, 2000, Hunger, 2007). The use of mordants in the present study produced no significant effect on the staining quality of both extracts as there was no difference between the staining reaction of the mordant and non-mordant preparation of this extract. This agreed with Avwioro et al., (2005b) who reported that mordants had no significant effect on the staining quality of some extracts. More so, several dyes such as eosin, neutral red and methylene blue do not require mordants before they can be used as stains (Baker et al., 2001; Avwioro, 2002). Contrarily, Hematoxylin, a natural histochemical and histological dye requires a mordant prior to staining (Bancroft and Layton, 2013).

It was observed that treatment with potassium permanganate was not necessary in enhancing the staining Fability of the extract but rather decolourized it from the colour it imparts on the tissue to a yellowish brown colour. It is well known that the staining property of Hematoxylin, haematin, may be obtained after oxidation by chemical agents [such as potassium permanganate and sodium iodate], which is termed a chemical ripening process (Bancroft and Layton, 2013), whereby the pale yellow-brown colour of hematoxylin is changed to deep mahogany brown after the oxidation. However, the effect observed with potassium permanganate treatment in the present study is not well understood. Further studies to elucidate this is required.

In conclusion Khaya senegalensis is a promising histological stain which is natural and readily available. The dye may also serve as a useful cytoplasmic stain to replace eosin in the Hematoxylin and eosin technique for histological diagnosis of diseases and demonstration of the normal histological architecture of tissues. 
Anatomy Journal of Africa. 2018. Vol 7 (2):1314 - 1321

\section{REFERENCES}

1. Abdel-Wareth AAA, Hammad S, Ahmed H. 2014. Efects of Khaya senegalensis leaves on performance, carcass traits, haematological and biochemical parameters in rabbits. EXCLI Journal. 13: 502.

2. Alturkistani HA, Tashkandi FM, Mohammedsaleh ZM. 2016. Histological Stains: A Literature Review and Case Study. Glob J Health Sci. 8(3): 72 - 79.

3. Atawodi SE. 2005. Comparative in vitro trypanocidal activites of petroleum ether, chloroform, methanol, and aqueous extracts of some Nigerian savannah plants. Afr. J. Biotechnol. 4(2): 177 $-182$.

4. Avwioro OG., Aloamaka PC., Ojianya NU, Oduola T, Ekpo EO. 2005a. Extracts of Pterocarpus osun as a histological stain for collagen fibres. African Journal of Biotechnology. 4(5): 460 462.

5. Avwioro OG., Awoyemi FA, Oduola T. 2005b. A novel natural collagen and muscle stain from Morinda lucida extracts. International Medical Journal. 4(2): $44-48$.

6. Avwioro OG., Onwuka S K, Moody J O, Agbedahunsi JM., Oduola T, Ekpo O E, Oladele AA. 2007. Curcuma longa extract as a histological dye for collagen fibres and red blood cells. Journal of Anatomy. 210: 600-603.

7. Avwioro OG. 2002. Histochemical and tissue pathology. $1^{\text {st }}$ edition. Claveranium Press, Ibadan, Nigeria. Pp. $134-143$.

8. Azubike NC, Achukwu PU, Okwuosa CN, Ajayi Y, Ugwu AC. 2011. Extracts of Lawsonia inermis and Hibiscus sabdarriffa as Stains for Histological Sections Journal of Science Engineering and Technology. 18 (1): 9944-9952.

9. Baker FJ, Silverton RE, Pallister CJ. 2001. Staining procedures. Introduction to Medical Laboratory Technology. $7^{\text {th }}$ edition, Bounty press limited, Ibadan Nigeria. pp225-48.

10. Bancroft JD, Layton C. 2013. The Hematoxylin and Eosin. In Suvarna SK, Layton C, Bancroft JD, editors. Theory Practice of Histological Techniques. $7^{\text {th }}$ ed. Philadelphia: Churchhill Livingstone of Elsevier.

11. Bhuyan R, Saika CN. 2004. Isolation of colour compounds from native dye - bearing plants in North-eastern India. American Journal of Pathology 164(5): 873 - 877.

12. Bokkestijn A, Francis JK. 1986. Khaya senegalensis Juss. Dry zone mahogany. SO - ITF - SM 5. Riopiedras, Institute of Tropical Forestry. Pp. 59-63.

13. Carleton HM., Drury, R.A.B., Wallington, F.A. and Cameron, R. 1976. Histological technique $4^{\text {th }}$ ed. Oxford University Press, London.

14. Eom S, Shin D, Yoon K. 2001. Improving the dyeability of natural colourants on cotton by cationization. Industrial Journal of Fibre and Textile Research. 26(4): 425 - 431.

15. Hill AF. 1952. Economical Botany. McGraw-Hill Book Company, Inc. New York. Pp. $40-46$.

16. Hoffman EM, Bauknecht N, 1999. A dye binding assay for the quantification of solution and cellbound acidic polysaccharides produced by red algae. Anal Biochem. 267(2): $245-251$.

17. Hunger K. (Ed.) 2007. Industrial dyes: Chemistry, Properties and Applications. Wiley - VCH Publishers, New York. Pp. $32-527$.

18. Jondiko IJO, Pattenden G. 1978. Terpenoids and an apocarotenoid from seeds of Bixa orellan. Phytochemistry. 28: $3159-3162$.

19. Kumar S, Singh NN, Singh A, Singh N, Sinha RK. 2014. Use of Curcuma longa L. extract to stain various tissue samples for histological studies. Ayu. 35(4): $447-451$.

20. Lamb FB. 1966. Mahogany of Tropical America. The University of Michigan Press, Ann Arbor, MI. Pp. 51-54.

21. Nikiema A, Pasternak D. 2008. Khaya senegalensis (Desr.) A. Juss. Plant resources of Tropical Africa. PROTA Foundation. 7: 339 - 344. 
22. Nwosu CU, Hassan SW, Abubakar MG, Ebbo AA. 2012. Anti-diarrhoeal and toxicological studies of leaf extracts of Khaya senegalensis. J. Pharmacol Tox. 7: 1-10.

23. Ochei J, Kolhaktar, A. 2000. Medical Laboratory Sciences. Theory and Practice Tata McGraw-Hill Publishing Company Limited, New Delhi. Pp. 437 - 444.

24. Okpidu EE, Okon AU, Oyadonghan GP, Ogbodo LA, Onyenekwe ECN. 2012. Histological study on the staining potentials of aqueous extract of Ceratonia silique bark. Interantional Journal of Basic, Applied and Innovative Research. 1(4): 151 - 1554.

25. Oliver-Bever BEP. 1960. Medicinal plants in Tropical West Africa. Cambridge University Press.

26. Orendu AM, Asala SA, Bedan HI, Hamman LL, Attah J. 2016. The effect of the Stem Bark of Khaya senegalensis on Wound Healing in Rabbits: A Preliminary Study. Nova. 5(4): 1-6.

27. Prentø P. 2009. Staining of macromolecules. Biotechnic and Histochemistry 84, 139-158.

28. Shahid A, Saukat A, Ijaz AB, Ferenc Z. 2009. Dyeing of cotton fabrics using pomegranate (Punica granatum) aqueous extract. Asian Journal of Chemistry. 21(5): 3493 - 3499.

29. Trease G, Evans SM. 2002. Pharmacognosy. 15th Edition, English Language Book Society, Bailliere Tindall, London. P 23-67

30. Vogt K. 1995. A field guide to the identification, propagation and uses of common trees and shrubs of dry land Sudan. S.O.S Sahel International (U.K). Pp. $70-79$.

31. Von Maydell HJ. 1986. Trees and shrubs of the Sahel - Their characteristics and uses. GT26MBH, Eschborn. Pp. $72-74$

32. Zhang $H$, Wang $X$, Chen $F$, Androulakis XM, Wargovich MJ. 2007. Anticancer activity of limonoid from Khaya senegalensis. Phytotherapy Research. 21(8): 731 - 734. 